medRxiv preprint doi: https://doi.org/10.1101/2022.01.15.22269360; this version posted January 18, 2022. The copyright holder for this preprint

(which was not certified by peer review) is the author/funder, who has granted medRxiv a license to display the preprint in perpetuity.

This article is a US Government work. It is not subject to copyright under 17 USC 105 and is also made available for use under a CCO license.

\title{
Effectiveness of mRNA COVID-19 Vaccines against Omicron among Veterans
}

Authors: Yinong Young-Xu, MA, MS, ScD ${ }^{1,2}$

Author Institutions/Affiliations:

1. White River Junction Veterans Affairs Medical Center, White River Junction, VT

2. Geisel School of Medicine at Dartmouth, Hanover, $\mathrm{NH}$

\section{Corresponding Author:}

Yinong Young-Xu

Veterans Affairs Medical Center

215 North Main Street

White River Junction, VT 05009

Yinong.Young-Xu@va.gov

$+1-802-295-9363 \times 6943$

Acknowledgements of research support for the study: This project was funded by the U.S. Department of Veterans Affairs (VA) Office of Rural Health.

Yinong Young-Xu had full access to all the data in the study and takes responsibility for the integrity of the data and the accuracy of the data analysis.

Disclaimer: This article represents the author's best judgement and should not bind or obligate the VA or any other institution.

Conflict of Interest Declaration: YYX acknowledges having received funding from Pfizer for other research projects but not this one. 
medRxiv preprint doi: https://doi.org/10.1101/2022.01.15.22269360; this version posted January 18, 2022. The copyright holder for this preprint (which was not certified by peer review) is the author/funder, who has granted medRxiv a license to display the preprint in perpetuity.

This article is a US Government work. It is not subject to copyright under 17 USC 105 and is also made available for use under a CCO license.

\begin{abstract}
Background: Effectiveness of mRNA vaccinations against Omicron among US veterans is unknown.
\end{abstract}

Objectives: To estimate mRNA COVID-19 vaccine effectiveness (VE) as measured by risk of SARS-CoV-2 infection.

Design, Setting, and Participants: This matched test-negative case-control study was conducted using SARS-CoV-2 test results at Veterans Health Administration sites from December 1, 2021, to December 31, 2021. VE against SARS-CoV-2 infection and COVID-19-related hospitalization and death were estimated using electronic health records from veterans who routinely sought care at a VHA facility and had a test result positive for SARS-CoV-2 (cases) or negative for SARS-CoV-2 (controls). Data were analyzed from December 1, 2021 to January 14, 2022.

Exposures: Vaccination status, defined as number of mRNA vaccine doses (1, 2, 3 or more) as the primary explanatory variable, at time of test.

Main Outcomes and Measures: The main outcome of interest was a positive result for SARSCoV-2 on a polymerase chain reaction or antigen test. Secondary outcomes included COVID19-related hospitalization and death, defined by discharge data and proximity of event to positive test result. VE was estimated from odds ratios for SARS-CoV-2 infection with 95\% CIs.

Results: VE for those who have received a mRNA vaccine booster is $77 \%$ (95\%, 75 to 79 ) against Delta while 62\% (95\%, 59 to 65) against Omicron infection, 91\% (95\%, 85 to 94) against COVID-related hospitalization with better VE against Omicron, and 96\% (95\%, 91 to 98) against COVID-related death with no discernable difference between Omicron and Delta. However, without a booster, VE against COVID-related death decreases to 76\% (95\%, 62 to 85).

Conclusions: Although Omicron is highly contagious and more likely to result in breakthrough infections against the current mRNA vaccines, a mRNA vaccine booster is still effective against severe COVID-related outcomes. 
medRxiv preprint doi: https://doi.org/10.1101/2022.01.15.22269360; this version posted January 18, 2022. The copyright holder for this preprint

(which was not certified by peer review) is the author/funder, who has granted medRxiv a license to display the preprint in perpetuity.

This article is a US Government work. It is not subject to copyright under 17 USC 105 and is also made available for use under a CCO license.

\section{Introduction}

In our first two articles ${ }^{1,2}$, we estimated the effectiveness of the mRNA vaccines against infection, hospitalization, and mortality among Veterans under the care of the Veterans Health Administration till the end of September 2021, covering major circulating variants in the United States such as Alpha, Beta, and Delta. With the rapid rise of the Omicron variant in December 2021, the nation is experiencing another surge in COVID infections and hospitalizations. Consequently, we aim to study mRNA vaccine effectiveness against the Omicron variant in the context of vaccine booster in the current analysis.

Methods

The study was approved by the institutional review board of the Department of Veterans Affairs Medical Center in White River Junction, Vermont, and was granted an exemption for consent because it was deemed impractical. This study followed the Strengthening the Reporting of Observational Studies in Epidemiology reporting guideline.

Electronic medical record data from the Veterans Health Administration Corporate Data Warehouse were analyzed. Based on variants tracking data ${ }^{3}$, we designated COVID infections occurred during December 2021 to be due to Omicron when infections occurred in a region where at least $70 \%$ of new infections were sequenced and found to be Omicron ${ }^{3}$. The rest were designated as Delta.

To estimate VE against infection, a matched case-control study was conducted, matching on region, sex, number of severe underlying conditions, and age categories (65 or older). Details of the methods have been published ${ }^{1}$. Conditional logistic regression was conducted with the number of mRNA vaccine doses $(1,2,3$ or more) as the primary explanatory variable. The regression model included indicator variables representing vaccination, SARS-CoV-2 variants (Omicron vs. Delta), and their interaction terms. The association between SARS-CoV-2 infections and vaccine booster was determined by estimating the odds ratio (OR) for the number of mRNA vaccine dosage, adjusting for additional variables including age and comorbid conditions. The reference group, unless specified otherwise, are those without any record of COVID vaccination, including J\&J/Janssen COVID-19 vaccine.

All tests were two-tailed, and 0.05 was the chosen level of statistical significance. Data analysis was performed using SAS 9.4 (SAS Institute, Cary, North Carolina).

Results

There were 14,868 veterans 18 or older with positive SARS-CoV-2 PCR test results, classified as cases, and 54,347veterans with negative test results, classified as matched controls. Of the entire study population of $69,215,30 \%$ had no record of any vaccination against COVID-19, while $31 \%$ had 3 or more doses of mRNA vaccines, $33 \%$ had 2 doses, and $6 \%$ with a record of one dose.

VE for those who have received a mRNA vaccine booster is $77 \%(95 \%, 75$ to 79$)$ against Delta while $62 \%(95 \%, 59$ to 65) against Omicron infection; In contrast, for those who have received 2 
medRxiv preprint doi: https://doi.org/10.1101/2022.01.15.22269360; this version posted January 18, 2022. The copyright holder for this preprint (which was not certified by peer review) is the author/funder, who has granted medRxiv a license to display the preprint in perpetuity. This article is a US Government work. It is not subject to copyright under 17 USC 105 and is also made available for use under a CCO license.

doses of mRNA vaccines, VE is $41 \%$ (95\%, 37 to 44) against Delta while 25\% (95\%, 20 to 30) against Omicron infection.

VE for those who have received a mRNA vaccine booster is $91 \%(95 \%, 85$ to 94$)$ against COVID-related hospitalization. Infection by Omicron has a 45\% (95\%, 26 to 58) lower likelihood of resulting in hospitalization than infection by Delta, although post-vaccine breakthrough infection is $87 \%$ (95\%, 65 to 111) more likely by Omicron than by Delta. Among COVID hospitalizations, Omicron is associated with a 2-day (95\%, 1 to 2) shorter stay than Delta where the length of stay averages 6 days (95\%, 5 to 7). Omicron is also associated with a $73 \%$ (95\%, 28 to 92) lower risk of being admitted to an intensive care unit (ICU).

Finally, VE for those who have received a mRNA vaccine booster is 96\% (95\%, 91 to 98) against COVID-related death with no discernable difference between Omicron and Delta. However, without a booster, VE against COVID-related death decreases to 76\% (95\%, 62 to 85).

\section{Discussion}

Our findings are aligned with other recent studies on mRNA vaccine effectiveness against Omicron $^{4,5}$. Omicron appears to be twice likely to break through current mRNA vaccines and cause infections than Delta. However, Omicron infections are less likely to result in hospitalization. Even when patients are hospitalized for Omicron infection, they tend to have a shorter length of stay and are less likely to be admitted to an ICU. Finally, those who received a mRNA vaccine booster are still highly protected against COVID-related deaths.

\section{Conclusion}

Although Omicron is highly contagious and more likely to result in breakthrough infections against the current mRNA vaccines, a mRNA vaccine booster is still effective against severe COVID-related outcomes.

\section{References}

1. Young-Xu Y, Korves C, Roberts J, et al. (2021). Coverage and effectiveness of mRNA COVID-19 vaccines among veterans: estimated from a test-negative case control study. JAMA Netw Open. 2021; 4(10)

2. Young-Xu Y, Zwain GM, Powell EI, et al. (2021) Estimated Effectiveness of COVID-19 Messenger RNA Vaccination Against SARS-CoV-2 Infection Among Older Male Veterans Health Administration Enrollees, January to September 2021. JAMA Netw Open. 2021;4(12).

3. https://www.cdc.gov/coronavirus/2019-ncov/variants/index.html; last accessed on January 15, 2022.

4. Collie S, Champion J, Moultrie H, Bekker LG, Gray G. Effectiveness of BNT162b2 Vaccine against Omicron Variant in South Africa. N Engl J Med. 2021 Dec 29: NEJMc2119270.

5.https://assets.publishing.service.gov.uk/government/uploads/system/uploads/attachment_data/f ile/1043807/technical-briefing-33.pdf 